\section{Spatial modeling of dengue and socio- environmental indicators in the city of Rio de Janeiro, Brazil}

\author{
Modelagem espacial da dengue e variáveis \\ socioambientais no Município do \\ Rio de Janeiro, Brasil
}

\author{
${ }^{1}$ Escola Nacional de Saúde \\ Pública Sergio Arouca, \\ Fundação Oswaldo Cruz, Rio \\ de Janeiro, Brasil. \\ 2 Programa de Computação \\ Científica, Fundação \\ Oswaldo Cruz, Rio de Janeiro, \\ Brasil. \\ Correspondence \\ T. R. A. Teixeira \\ Programa de Computação \\ Científica, Fundação Oswaldo \\ Cruz. \\ Av. Brasil 4365, Rio de Janeiro, \\ RJ 21045-900, Brasil. \\ tatirodriguesaraujo@yahoo. \\ com.br
}

\section{Abstract}

This study analyzed the spatial distribution of dengue in Rio de Janeiro, Brazil, in 2006, and associations between the incidence per 100,000 inhabitants and socio-environmental variables. The study analyzed reported dengue cases among the city's inhabitants, rainfall, Breteau index (for Aedes aegypti and Aedes albopictus), Gini index, and social development index. We conducted mapping and used the global Moran index to measure the indicators' spatial autocorrelation, which was positive for all variables. The generalized linear model showed a direct association between dengue incidence and rainfall, one-month rainfall time lag, Gini index, and Breteau index for A. albopictus. The conditional autoregressive model (CAR) showed a direct association with rainfall for four months of the year, rain time lag in July, and Gini index in February. The results demonstrate the importance of socio-environmental variables in the dynamics of dengue transmission and the relevance for the development of dengue control strategies.

Dengue; Ecological Studies; Environmental Indicators; Spatial Analysis
Tatiana Rodrigues de Araujo Teixeira 1,2 Oswaldo Gonçalves Cruz 2

\section{Introduction}

Dengue is currently the most important mosquito-borne human viral disease in terms of epidemiological magnitude. The main vector, Aedes aegypti, found favorable conditions for its proliferation in Brazil, thus greatly facilitating spread of the disease, also favored by the country's rapid urbanization and population growth, combined with inefficient vector control programs 1 .

Dengue epidemics involve complex dynamics between the human and vector populations, with a major influence from environmental factors like weather conditions and the various species' capacity to adapt to different ecological and social contexts 2 .

Disorderly urbanization and the resulting production of areas with high human population density and deficient water supply and waste disposal, together with inefficient vector control, produce a highly complex manmade environment. It thus is essential to rethink dengue control, which requires integrated policies between various sectors of society, since mitigation of the epidemic process has been a function of herd immunity and depletion of susceptible individuals rather than efficient vector control ${ }^{3}$.

Various authors have studied the association between dengue incidence and socioeconomic and environmental indicators. Some studies have analyzed the relationship between dengue and 
socioeconomic conditions in Brazilian metropolises 4,5,6,7,8,9,10. Ribeiro et al. 11 analyzed associations between dengue and climatic variables like temperature and rainfall. Others studies have evaluated the association between dengue and vector infestation rates 12,13,14.

Studies on dengue and socioeconomic and environmental indicators have not all produced concordant results 15 , since most analyze the variables separately. In addition, Flauzino et al. 15 found no modeling analysis on dengue that simultaneously approached socioeconomic indicators and environmental variables like rainfall and vector infestation, which would allow a more comprehensive analysis of the dynamics in the spread of dengue in the urban setting.

In 2006, Brazil accounted for $85 \%$ of all dengue cases reported in South and Central America. As of the $30^{\text {th }}$ epidemiological week of 2010, 234,068 cases of classic dengue had been reported in the country, with 346 manifestations of dengue hemorrhagic fever 16. The Municipality (county) of Rio de Janeiro had 14,113 cases, of which 12,572 occurred from January to May, with the peak in the month of March. During the same year, the overall incidence rate for the Municipality was 240.9 cases per 100 thousand inhabitants 17 . The year 2006 was chosen because it was the last epidemic year at the time the data were collected for the study, and because it was a year for which data were available for all the other variables selected for the modeling.

Given this context, the current study analyzed dengue spatial distribution in the Municipality of Rio de Janeiro in the year 2006 and evaluated its relationship to environmental and socioeconomic variables simultaneously, using spatial statistical modeling.

\section{Material and methods}

Located in the Southeast Region of Brazil, the Municipality of Rio de Janeiro has a population of $6,093,472$ and a total area of $1,182 \mathrm{~km}^{2}$ (Instituto Brasileiro de Geografia e Estatística - IBGE; http: / /www.ibge.gov.br, accessed Jul/2008), characterized by high population density and social inequalities, with a large share of the population in precarious living conditions, such as favelas (slums).

This study adopted an analytical ecological design. The analytical units were 157 of the 160 neighborhoods in the city of Rio de Janeiro. The neighborhoods Vasco da Gama, Parque Colúmbia, and Gericinó, created since 1998, were maintained aggregated with their original neighborhoods (São Cristóvão, Pavuna, and Bangu, respectively) ${ }^{18}$. This aggregation was used because the current article involves a section of a spatial dengue analysis that covered the period from 1996 to 2006 19, such that the same abovementioned spatial base was maintained for all the years in order to allow comparability between the maps.

We studied reported dengue cases among individuals residing in the Municipality of Rio de Janeiro, Brazil, from January to December 2006, obtained from the Information System on Diseases of Notification (SINAN), made available by the Epidemiological Surveillance Division of the Rio de Janeiro Municipal Health Department. There was a $0.25 \%$ loss of information in georeferencing the cases, since 561 of the 221,067 reported cases in the database were missing the item "neighborhood" and these cases were thus excluded from the analysis.

A population projection by neighborhood was performed for the year 2006, based on population data from the 1991 and 2000 censuses, available at the Data Storage site of the Rio de Janeiro Municipal Government (Instituto Municipal de Urbanismo Pereira Passos - IPP. Estatísticas municipais; http://www.armazemdedados. rio.rj.gov.br, accessed Jan/2009).

The neighborhood dengue incidence rate per 100 thousand inhabitants was calculated for the year 2006. The analysis considered incidence on a log scale, with the aim of conducting an approximation for normal distribution.

The following explanatory variables were studied: precipitation; building infestation index; and Breteau index for A. aegypti and the same indices for Aedes albopictus (for the month of January 2006); and socioeconomic variables: social development index, municipal human development index, and four indicators of income and inequality (ratio between the mean income of the wealthiest $10 \%$ and the poorest $40 \%$; ratio between the mean income of the wealthiest $20 \%$ and the poorest $40 \%$; Gini index; and Theil-L index).

We performed an exploratory analysis and evaluation of colinearity among the variables, having selected 5 of 11 the above-mentioned variables for the analysis: rainfall; Breteau index for A. aegypti and A. albopictus (for the month of January 2006); and the socio-demographic variables social development index and Gini index. The sources for the selected variables are described next.

Data were obtained on monthly accumulated rainfall, in millimeters, for the months from December 2005 to December 2006, through the Rio de Janeiro Municipal Geotechnical Institute Foundation - GEORIO (Dados pluviométricos: 
acumuladas mensais. http://www.rio.rj.gov.br/ georio/alerta/tempo.html, accessed Jul/2008).

For rainfall, it was necessary to perform spatial interpolation using the kriging method, since this variable is not measured in all the neighborhoods, but with 32 weather stations. Kriging is a statistical modeling of global and local effects, where the value of a variable at each point on a surface can be estimated 20 . The interpolation considered simple kriging, where the grid corresponded to the centroids of the 157 neighborhoods. Later, kriging was performed with a $100 \times 100$ cell grid, with the objective of spatial smoothing for better visualization of the maps. Two variables were created with the precipitation data: rainfall (rainfall in the months of 2006), and rainfall lag (rainfall lag, referring to the previous month). For example, for the month of January 2006, a rainfall lag for the precipitation from December 2005 was considered.

The building infestation index and the Breteau indices for A. aegypti and A. albopictus were obtained from the Zoonosis Control Center of the Rio de Janeiro Municipal Health Department. We only used infestation data for the month of January 2006, since this was the only month for which data were available for all the neighborhoods. Therefore, data for the other months were not used, only because they were not completely available. It is also important to underscore this indicator's low trustworthiness and reliability.

The social development index is a summary indicator that represents four major dimensions: housing conditions, sanitation, schooling, and income. This indicator was calculated based on ten variables from the Demographic Census, 2000 conducted by the Brazilian Institute of Geography and Statistics (IBGE) 21.

The Gini index represents the degree of inequality in the distribution of individuals according to per capita household income. It is one of the most well-known measures of the degree of income concentration. The index varies from 0 , when there is no inequality (all individuals have the same income), to 1 , when inequality is maximum 22 . The social development index and Gini index were obtained from the Data Storage site of the Rio de Janeiro Municipal Government (IPP. Estatísticas municipais. http://www.armazemdedados.rio.rj.gov.br, accessed Jan/2009).

Thematic mapping was performed for the outcome variable and explanatory variables. Based on the values predicted with the kriging method, interpolated rainfall maps were created for the municipality for the 2006, month-bymonth. The maps were prepared using a digital map base for the municipality, obtained through the Geoprocessing Laboratory of the Health Information Department of the Institute of Communication and Scientific and Technological Information in Health (ICICT/FIOCRUZ).

Global spatial auto-correlation analysis was performed for all the variables, by constructing a neighborhood matrix by contiguity, based on the first-order neighbor criterion. The global Moran index was applied, which allowed verifying whether neighboring areas display greater similarity for the target indicator than expected by chance; a positive result indicates direct correlation and a negative result indicates inverse autocorrelation 23 .

The modeling used the generalized linear model (GLM) from the Gaussian family and the conditional autoregressive (CAR) spatial model. The CAR model used the same variables as in the previous model, aimed at comparability among the models. However, it was not possible to conduct the CAR model using this same set of data, because in this set the variables were arranged by month, thus considering a temporal structure. The presence of the temporal structure prevents the application of the CAR model, since this spatial model only incorporates the spatial structure, and does not deal with the data's temporal structure. Thus, we isolated the temporal structure and only analyzed the data's spatial structure, using CAR modeling for each month separately. The analysis, spatial auto-correlation test, and residual maps were performed for the GLM and CAR models.

Statistical analysis of the data, generation of the maps, and modeling used R 2.7.1 (The R Foundation for Statistical Computing, Vienna, Austria; http://www.r-project.org).

The following R libraries were used: Spdep (Spatial dependence: weighting schemes, statistics, and models. http://sourceforge.net/proj ects/spdep, accessed Aug/2008); RColorBrewer (http://crantastic.org/packages, accessed Aug/2008), and geoR (geoR: a package for geostatistical analysis using the R software. http:// www.est.ufpr.br/geoR, accessed Aug/2008).

The study was approved by the Institutional Review Board of ENSP/FIOCRUZ, case number CAAE 0074.0.031.000-08.

\section{Results}

Mapping of incidence in the year 2006 showed the highest rates in the neighborhoods from the Administrative Regions (ARs), or boroughs, of Jacarepaguá, Cidade de Deus, and Barra da Tijuca, especially the following neighborhoods: Vargem Grande, Vargem Pequena, Camorim, 
Taquara, Curicica, Cidade de Deus, and Jacarepaguá. High incidence rates were also seen in neighborhoods from the following ARs: Centro (Downtown), Portuária (Port District), and Rio Comprido (Figure 1).

As for the rainfall maps, the month of January was the rainiest, with the highest intensity in the vicinity of the Cidade de Deus, Tanque, and Madureira weather stations. The driest months were July and August. The Sumaré weather station, located in a higher neighborhood, Alto da Boa Vista, showed consistently higher rainfall levels, even in drier months (Figure 2).
The distribution maps for the other explanatory variables showed the highest Breteau indices for both vector species in the neighborhoods from the Méier and Inhaúma Administrative Regions and the Glória neighborhood. The highest social development indices were in the neighborhoods located in the city's Zona Sul or South Side (Botafogo, Copacabana, and Lagoa ARs) and in the Barra da Tijuca neighborhood. Distribution of the Gini index showed the worst social inequality in a major portion of the neighborhoods in the Barra da Tijuca, Jacarepaguá, Guaratiba, Lagoa, and Santa Teresa ARs (Figure 3).

Figure 1

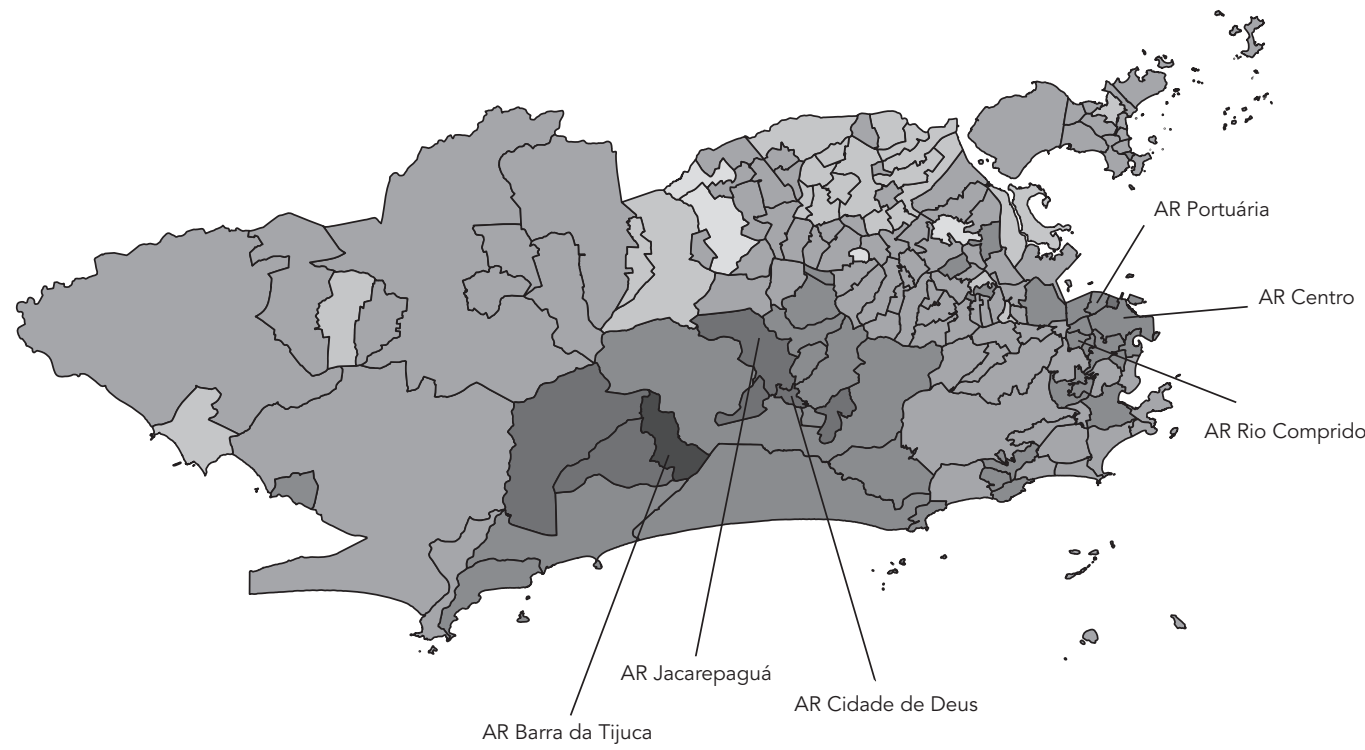

No case

0.0 to 1.4 (incidence of 1.00 to $4.05 / 100,000$ )

1.4 to 2.8 (incidence of 4.05 to $16.44 / 100,000$ )

2.8 to 4.2 (incidence of 16.44 to $66.68 / 100,000$ )

4.2 to 5.6 (incidence of 66.68 to $270.42 / 100,000$ )

5.6 to 7 (incidence of 270.42 to $1,096.63 / 100,000$ )

7 to 8.4 (incidence of $1,096.63$ to $4,447.06 / 100,000$ )
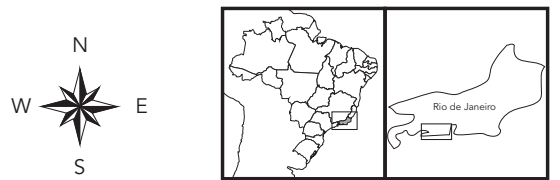

8.4 to 9.8 (incidence of $4,447.06$ to $18,033.74 / 100,000$ )

$\geq 9.8$ (incidence more than 18,033.74 / 100,000)

AR: Administrative Region. 

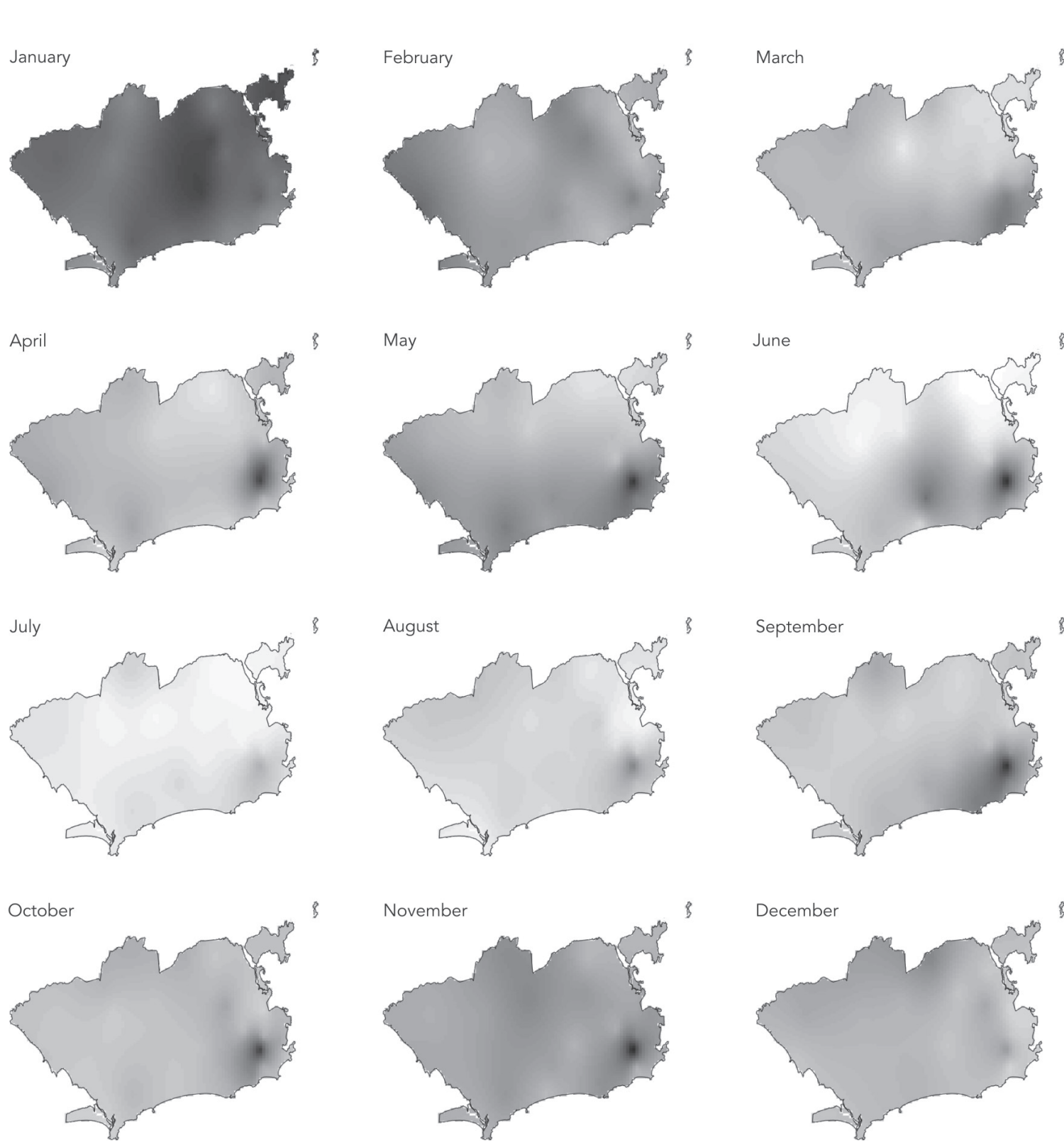

The results showed a statistically significant global Moran index $(\mathrm{p}<0.05)$ for both dengue incidence and all the explanatory variables, but only rainfall and the social development index showed strong auto-correlation. This means that there was an overall pattern of spatial de- pendence in the distribution of these indicators, i.e., contiguous neighborhoods displayed greater similarity than distant neighborhoods (Table 1).

Generalized linear modeling (GLM, from the Gaussian family) produced a final model showing significant direct association between den- 
Distribution maps for explanatory variables: Breteau index for Aedes aegypti, Breteau index for Aedes albopictus, social development index, and Gini index. Municipality of Rio de Janeiro, Brazil, 2006.

3a) Breteau index for Aedes aegypti

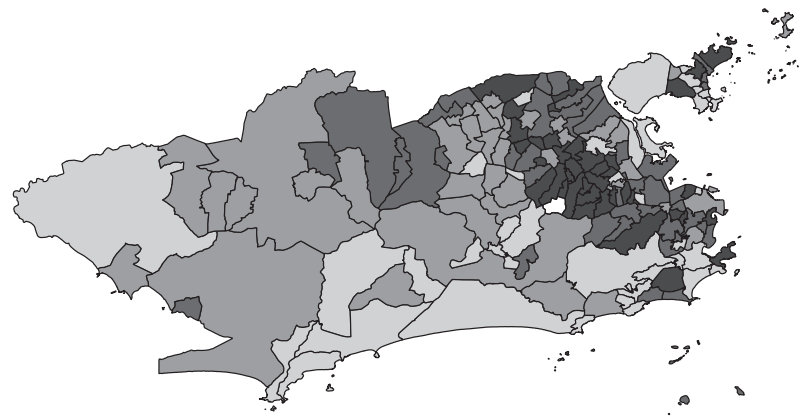

0.00 to 2.04

2.05 to 6.7

6.71 to 13.14

13.15 to 40.63 3b) Breteau index for Aedes albopictus

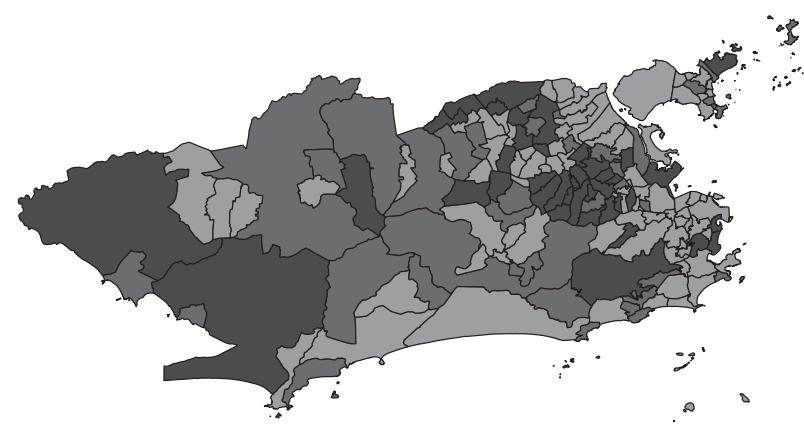

0.00

0.01 to 0.45

0.46 to 0.89

0.90 to 13.34
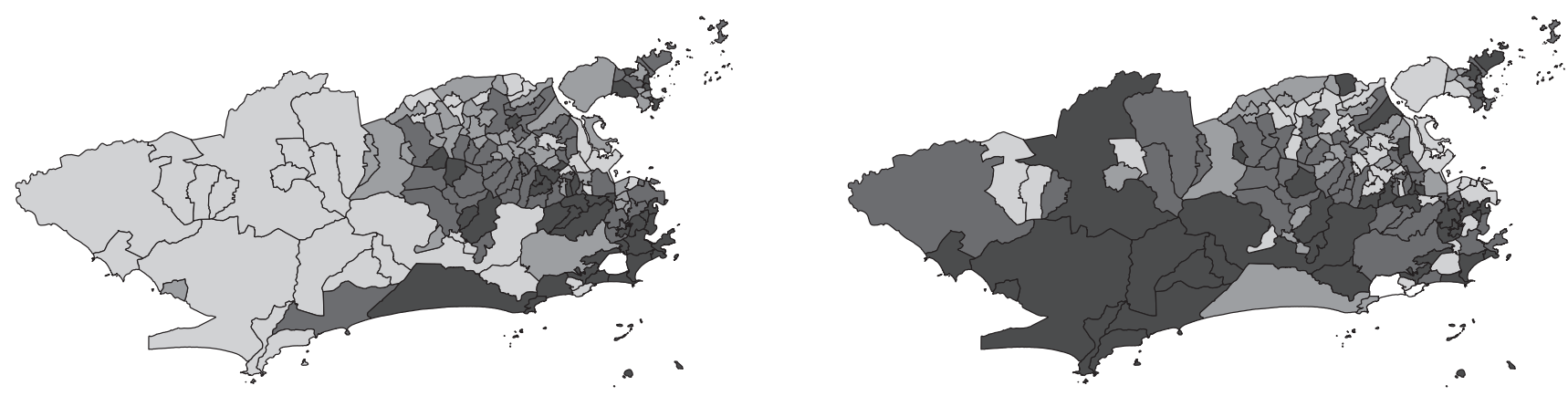

0.28 to 0.54

0.40 to 0.47

0.55 to 0.59

0.48 to 0.49

0.60 to 0.65

0.50 to 0.52

0.66 to 0.85

0.53 to 0.74

gue incidence and the following variables: rainfall, rainfall lag, Gini index, and Breteau index for A. albopictus, but only the Gini index showed a strong association. The Breteau index for
A. aegypti showed a weak inverse association with dengue incidence. The social development index was the only variable for which no association was found. In this model, the months were con- 


\section{Table 1}

Global Moran index for the outcome variable, explanatory variables, and generalized linear models (GLM) by months, according to significance levels. Municipality of Rio de Janeiro, Brazil, 2006.

\begin{tabular}{|c|c|c|}
\hline Variables & Global Moran index & p-value \\
\hline Dengue incidence in 2006 & 0.4924 & $<0.0001$ \\
\hline January & 0.1761 & 0.0001 \\
\hline February & 0.242 & $<0.0001$ \\
\hline March & 0.2279 & $<0.0001$ \\
\hline April & 0.2947 & $<0.0001$ \\
\hline May & 0.2551 & $<0.0001$ \\
\hline June & 0.1262 & 0.005 \\
\hline July & 0.1048 & 0.0157 \\
\hline August & 0.0954 & 0.0244 \\
\hline September & 0.1673 & 0.0003 \\
\hline October & 0.1293 & 0.0043 \\
\hline November & 0.1044 & 0.016 \\
\hline December & 0.0998 & 0.0199 \\
\hline \multicolumn{3}{|l|}{ Rainfall } \\
\hline January & 0.867 & $<0.0001$ \\
\hline February & 0.7937 & $<0.0001$ \\
\hline March & 0.9347 & $<0.0001$ \\
\hline April & 0.7365 & $<0.0001$ \\
\hline May & 0.924 & $<0.0001$ \\
\hline June & 0.8318 & $<0.0001$ \\
\hline July & 0.9113 & $<0.0001$ \\
\hline August & 0.8383 & $<0.0001$ \\
\hline September & 0.8494 & $<0.0001$ \\
\hline October & 0.7115 & $<0.0001$ \\
\hline November & 0.7389 & $<0.0001$ \\
\hline December & 0.8478 & $<0.0001$ \\
\hline Breteau index for Aedes aegypti & 0.2842 & $<0.0001$ \\
\hline Breteau index for Aedes albopictus & 0.0958 & 0.0128 \\
\hline Social development index & 0.5207 & $<0.0001$ \\
\hline Gini index & 0.27 & $<0.0001$ \\
\hline \multicolumn{3}{|l|}{ GLM } \\
\hline January & 0.1325 & 0.0035 \\
\hline February & 0.1913 & $<0.0001$ \\
\hline March & 0.1598 & 0.0005 \\
\hline April & 0.1852 & $<0.0001$ \\
\hline May & 0.1521 & 0.001 \\
\hline June & -0.0256 & 0.6452 \\
\hline July & 0.0447 & 0.1614 \\
\hline August & -0.0064 & 0.0859 \\
\hline September & 0.1357 & 0.0029 \\
\hline October & 0.1112 & 0.0114 \\
\hline November & 0.0821 & 0.0433 \\
\hline December & 0.0591 & 0.1023 \\
\hline
\end{tabular}

sidered explanatory variables, and the months of February, March, April, and May were directly and strongly associated with dengue incidence. The months of October and November showed 
a strong inverse association (Table 2). Thus, we observed the influence of the months' temporal pattern on dengue incidence.

To verify the model's goodness-of-fit, we performed a residuals analysis, the results of which showed a good fit. To test the spatial auto-correlation for the residuals from the final model, GLM models were considered for the 12 months, and residual maps were constructed for the monthly models. For most of the months, the maps showed large clusters of positive and negative residuals, indicating significant spatial dependence, with the exception of June, July, August, and December (Table 1). This factor justifies the use of the CAR spatial modeling, capable of capturing the data's spatial structure.

Analysis of the results of the CAR modeling showed that the spatial modeling isolated by month lost the previously observed effect of the variables (when we considered all the months' temporal pattern jointly). Few variables were significant ( $\mathrm{p}<0.05$ ): in January, the rainfall variable, with direct association (coefficient 0.0193) and the Breteau index for A. albopictus with an inverse association (coefficient -0.3066); February, Gini index with a strong direct association (coefficient 12.5423); March, May, and June, rainfall, with direct association (coefficients 0.0102,
0.0233, and 0.0242, respectively); and July, with the rainfall lag variable, with direct association (coefficient 0.0196). For the months of April, August, September, October, November, and December, no statistically significant associations were observed between dengue incidence and any variable.

The residual maps for the CAR models showed random distribution of the residuals for the 12 models. The residuals' spatial auto-correlation was tested, proving spatial independence for all the months, which shows that the model captured the data's spatial dependence structure.

\section{Discussion}

The city of Rio de Janeiro is an area with wide environmental and socioeconomic diversity. Its physical geography, with numerous mountains and lowlands, involves various problems with rainfall runoff, combined with the disordered occupation of the city's hillsides 24 . The city is characterized by numerous contrasts, with extremely wealthy areas with excellent quality of life, very close to areas lacking minimum sanitation and garbage collection. The socioeconomic disparities are often geographically close to each other,

Table 2

\begin{tabular}{|c|c|c|c|c|}
\hline Model/Variable & Coefficient & Standard error & t-test & p-value \\
\hline \multicolumn{5}{|l|}{ GLM } \\
\hline Intercept & -0.1612 & 0.4006 & -0.403 & 0.6873 \\
\hline Rainfall & 0.0036 & 0.0010 & 3.592 & 0.0003 \\
\hline Rainfall lag & 0.0029 & 0.0010 & 2.860 & 0.0043 \\
\hline Social development index & -0.0405 & 0.3563 & -0.114 & 0.9093 \\
\hline Gini index & 3.4015 & 0.6397 & 5.317 & $<0.0001$ \\
\hline Breteau index for Aedes aegypti & -0.0133 & 0.0043 & -3.049 & 0.0023 \\
\hline Breteau index for Aedes albopictus & 0.0605 & 0.0231 & 2.612 & 0.0091 \\
\hline January & -0.3101 & 0.2638 & -1.175 & 0.2400 \\
\hline February & 0.6399 & 0.2346 & 2.727 & 0.0064 \\
\hline March & 1.5375 & 0.1605 & 9.577 & $<0.0001$ \\
\hline April & 1.5135 & 0.1561 & 9.696 & $<0.0001$ \\
\hline May & 0.8754 & 0.1648 & 5.309 & $<0.0001$ \\
\hline June & 0.1979 & 0.1614 & 1.226 & 0.2203 \\
\hline August & 0.3352 & 0.1786 & 1.877 & 0.0607 \\
\hline September & -0.3087 & -0.1899 & -1.626 & 0.1042 \\
\hline October & -0.6376 & 0.1926 & -3.310 & 0.0009 \\
\hline November & -0.7604 & -0.2126 & -3.576 & 0.0003 \\
\hline December & -0.3610 & 0.1955 & -1.846 & 0.0651 \\
\hline
\end{tabular}


and the urban slums (favelas) are distributed throughout the city.

As in the current study, Almeida et al. ${ }^{4}$ also found significant spatial auto-correlations between the city's neighborhoods in the 2002 dengue epidemic. Neighborhoods located in the city's Zona Oeste (West Side) and the Jacarepaguá, Cidade de Deus, and Barra da Tijuca ARs, which showed the highest incidence rates in both studies, were the ones with the most recent urban occupation, and many still suffer from precarious infrastructure conditions. A major portion of the West Side still has a precarious sewage system 25 . Meanwhile, the neighborhoods close to the city center (Centro) and the neighborhoods in the Zona Norte (North Side) have a better infrastructure, but are characterized by high urban population density and the highest concentration of favelas in the city 25 .

The city's above-mentioned characteristics are consistent with our finding of a strong direct association between the Gini index and dengue incidence, since this index expresses social inequality 22 . As we found in this article, higher Gini index (or greater inequality) is associated with higher dengue incidence. Meanwhile, no association was found between dengue incidence and social development index. This finding was surprising and somewhat controversial, because as discussed previously, higher dengue incidence rates were found in neighborhoods with more precarious infrastructure.

Studies investigating the association between dengue and socioeconomic variables have produced conflicting results. The relationship between dengue incidence and socioeconomic levels is difficult to measure, since there are diverse and complex variables involved in this process requiring information that is rarely available for aggregate data, besides sophisticated models for the detection of such associations.

The studies demonstrated a positive association between increased risk of dengue transmission and worse socioeconomic levels in the population: Costa \& Natal 5 , in the city of São José do Rio Preto (São Paulo State); Caiaffa et al. 6, in the city of Belo Horizonte (Minas Gerais State); Teixeira \& Medronho 7, in the State of Rio de Janeiro; and Siqueira et al. 8 in the city of Goiânia (Goiás State).

Teixeira \& Medronho 7, in a study on dengue incidence in the State of Rio de Janeiro, found a direct correlation between dengue incidence and higher proportion of urban (as opposed to rural) population, and an inverse correlation between dengue incidence and percentage of the population with running water, a variable that reflects housing conditions and serves as one of the com- ponents in calculating the social development index. Conditions like water supply, adequate sewage treatment, and garbage collection are related to socioeconomic levels and are known to be related to dengue transmission 26 .

Mondini \& Chiaravalloti Neto ${ }^{9}$, in a study in the city of São José do Rio Preto, São Paulo State, from September 1994 to August 2002, found spatial auto-correlation for dengue incidence throughout the study period, using the global and local Moran index. The authors detected clusters of increased dengue incidence in the census tracts with the worst socioeconomic levels. Five socio-environmental variables were found that explained dengue incidence, including the percentages of households without running water or garbage collection, respectively.

On the other hand, Mondini \& Chiaravalloti Neto 10 , in another study in the same city from September 1990 to August 2002, investigated the association between a summary socioeconomic factor that accounted for $87 \%$ of the total variability in the socioeconomic variables, and dengue incidence, and found no association between risk of occurrence of the disease and socioeconomic levels in nearly all of the 12 years.

Although the socioeconomic variables were not the principal factors explaining dengue incidence, they are important for explaining part of the phenomenon. It is thus essential to develop public policies for interventions aimed at improving these indicators, which would definitely have a major impact and reduce dengue transmission.

According to Flauzino et al. 15, some authors indicate a proportionally inverse association between dengue incidence and living conditions, while others point to a positive association. It is suggested that differences between the associations found in different studies may be related to the type of spatial unit used, or that depending on the level of aggregation of explanatory variables, there could occur a major variation in the results, especially in the presence of socioeconomic and infrastructural inequalities. In the above-mentioned review, studies with secondary data that used the same type of special aggregation showed similar results 15 .

The current study showed a direct association between dengue incidence and rainfall, in both the final generalized linear model and some monthly CAR models. In addition, a direct association was found between dengue incidence and a one-month rainfall time lag, i.e., cases in a given month correlated with rainfall from both the same month and from the previous month.

Ribeiro et al. 11, in a study on dengue incidence in the city of São Sebastião (São Paulo 
State) in 2001 and 2002, investigated the association between the number of dengue cases and the climatic variables rainfall and temperature, first considering these three variables occurring in the same month, and then considering the time between the biological fact, transmission, and reporting of cases. No association was observed between mean monthly rainfall and the number of cases in the same month of analysis. The correlation began to appear when the values for the abiotic factors from a given month were considered with the number of cases in the subsequent month. This time lag showed a significant association in the second, third, and fourth month of observation, i.e., rainfall and temperature in a given month helped explain the number of dengue cases up to four months later, thus characterizing a seasonal rainfall pattern.

Another finding in our study was the significant association between dengue incidence and the Breteau index for A. aegypti (weak inverse association) and A. albopictus (weak direct association) in the final GLM. This inverse association between dengue incidence and the Breteau index for A. aegypti in the year 2006 may be explained as follows: heavily infested areas may already have been extensively affected by the disease in previous years, and the depletion of susceptible individuals may have led to low dengue incidence in 2006 in highly infested areas. Meanwhile, infestation by A. albopictus was directly associated with dengue incidence; importantly, infestation with this wild vector is much lower than infestation with the urban vector, even in areas with a low index. However, although there are few areas in which the Breteau index for A. albopictus is higher, there is a significant (but weak) direct association between the vector's presence and greater incidence of the disease. It is also important to note that dengue transmission by this vector has still not been proven, a fact observed in a previous study, the results of which suggest that the species can still not be considered an inter-human vector during dengue epidemics in Brazil 27.

One of the few studies that indirectly demonstrated a correlation between the building infestation index and the number of dengue cases was the work by Cunha et al. 12, suggesting a relationship between low number of cases and low infestation index in the Municipality of Paracambi (Rio de Janeiro State). The authors related the low dengue activity between 1991 and 1994 to the low building infestation index with $A$. aegypti, despite the high index for A. albopictus during the same period.

Corrêa et al. 13 observed a weak but statistically significant correlation between monthly dengue incidence rate and building infestation indices for the health districts and coverage areas in the city of Belo Horizonte, Minas Gerais State, from October 1997 to May 2001, showing that higher indices were associated with increased risk of dengue transmission.

Coelho et al. 14 tested the correlation between the Larval Index Rapid Assay (LIRA) and dengue incidence rate, force of infection, and basic reproduction number $\left(\mathrm{R}_{0}\right)$ for 61 Brazilian cities from October 2006 to July 2007. A direct correlation was found between larval index and force of infection and between the index and the basic reproduction number, but no correlation was found with the incidence rate per 100 thousand inhabitants.

As observed in this study, given the precarious reliability and data availability for the Breteau index (one of the main vector infestation indices among those cited above), one should note that in 2001 the Brazilian Ministry of Health proposed the Plan for Intensification of Dengue Control Activities. The plan included the improvement and integration of entomological and epidemiological surveillance in order to increase the capacity for prediction and detection of epidemics 28 . For entomological surveillance, the plan proposed to measure the building infestation index and the proportion of permanent vector breeding sites per household. The plan aims to reduce the infestation index to less than $1 \%$. However, the current study has shown that such indices are neither trustworthy nor effectively usable, given the results discussed above. Importantly, the infestation rates (as used) do not directly express the mosquito population density, since they fail to take the breeding sites' productivity into account 29 .

This study allowed detecting the association between dengue incidence and social inequality, represented by the Gini index, and between vector infestation and rainfall. Thus, we observed the importance of the socio-environmental context in the dynamics of dengue transmission and the relevance of these indicators to back strategies to control the endemic. The study also allowed identifying areas in the Municipality of Rio de Janeiro with greater risk of occurrence of dengue, that is, areas with increased density of dengue incidence and thus greater risk of the illness: the neighborhoods in the Administrative Regions of Jacarepaguá, Cidade de Deus, Barra da Tijuca, Centro (Downtown), Portuária (Port District), and Rio Comprido. The detection of areas that call for greater attention is an essential element for optimization of resources in the implementation of control strategies, targeting priority areas, thus potentially producing better results by reducing incidence rates. 
A major methodological problem is data georeferencing, due to the incomplete data on the epidemiological notification forms 22 . Often the address is either missing entirely or it is impossible to locate, especially in the favelas, thus suggesting a potential selection bias for studies like this one. Efforts have focused on improving the recording of addresses in these communities, which could greatly facilitate the application of more precise geocoding. The current study showed a tiny percentage of missing information, with only $0.25 \%$ of cases excluded due to lack of

\section{Resumo}

Analisaram-se a distribuição espacial da dengue na cidade do Rio de Janeiro, Brasil, em 2006, e associações entre sua incidência por 100 mil habitantes e variáveis socioambientais. Consideraram-se os casos notificados de residentes no município, o índice pluviométrico, o índice de Breteau (para Aedes aegypti $e$ Aedes albopictus), o índice de Gini e o índice de desenvolvimento social. Realizou-se o mapeamento e mensurouse a autocorrelação espacial dos indicadores pelo índice global de Moran, sendo essa positiva para todas as variáveis. O modelo linear generalizado evidenciou associação direta entre a incidência e chuva; time-lag de um mês para chuva; índice de Gini e indice de Breteau para Aedes albopictus. Através do modelo espacial CAR (conditional autoregressive), encontrou-se associação direta com chuva em quatro meses do ano; time-lag de chuva em julho e índice de Gini em fevereiro. Esses resultados evidenciam a importância de variáveis socioambientais na dinâmica de transmissão da dengue, e sua relevância como subsídios às estratégias de controle.

Dengue; Estudos Ecológicos; Indicadores Ambientais; Análise Espacial information on the neighborhood (thereby preventing georeferencing of the case).

The study identified the need to investigate and analyze the association between dengue incidence and explanatory variables through more complex models, such as a complete Bayesian model, which would be capable of simultaneously capturing the spatial and temporal autocorrelation structures, allowing a better understanding of the dynamics in the transmission and spread of dengue in the urban territory.

\section{Contributors}

T. R. A. Teixeira participated in the literature review, data collection, processing, and analysis, discussion of the results, elaboration of the article, and final version. O. G. Cruz collaborated in the definition of the methodological design, data analysis, revision and discussion of the results, and revision of the final version.

\section{Acknowledgments}

The authors wish to thank Cecília Nicolai and the entire staff at the Epidemiological Surveillance Division of the Rio de Janeiro Municipal Health Department for kindly ceding the data for this article and the Graduate Studies Program at the Sergio Arouca National School of Public Health, Oswaldo Cruz Foundation (ENSP/FIOCRUZ) for the learning opportunities and professional growth provided by the Master's Course. 


\section{References}

1. Teixeira MG, Costa MCN, Barreto ML, Mota E. Dengue and dengue hemorrhagic fever epidemics in Brazil: what research is needed based on trends, surveillance, and control experiences? Cad Saúde Pública 2005; 21:1307-15.

2. Donalísio MR, Glasser CM. Vigilância entomológica e controle de vetores do dengue. Rev Bras Epidemiol 2002; 5:259-72.

3. Medronho RA. Dengue e o ambiente urbano. Rev Bras Epidemiol 2006; 9:159-61.

4. Almeida AS, Medronho RA, Valencia IO. Análise espacial da dengue e o contexto socioeconômico no município do Rio de Janeiro, RJ. Rev Saúde Pública 2009; 43:666-73.

5. Costa AIP, Natal D. Distribuição espacial da dengue e determinantes socioeconômicos em localidade urbana no Sudeste do Brasil. Rev Saúde Pública 1998; 32:232-6.

6. Caiaffa WT, Almeida MCM, Oliveira CL, Friche AAL, Matos SG, Dias MAS, et al. The urban environment from the health perspective: the case of Belo Horizonte, Minas Gerais, Brazil. Cad Saúde Pública 2005; 21:958-67.

7. Teixeira TRA, Medronho RA. Indicadores sóciodemográficos e a epidemia de dengue em 2002 no Estado do Rio de Janeiro, Brasil. Cad Saúde Pública 2008; 24:2160-70.

8. Siqueira JB, Martelli CM, Maciel IJ, Oliveira RM, Ribeiro MG, Amorim FP, et al. Household survey of dengue infection in Central Brazil: spatial point pattern analysis and risk factors assessment. Am J Trop Med Hyg 2004; 71:646-51.

9. Mondini A, Chiaravalloti Neto F. Spatial correlation of incidence of dengue with socioeconomic, demographic and environmental variables in a Brazilian city. Sci Total Environ 2008; 393:241-8.

10. Mondini A, Chiaravalloti Neto F. Variáveis socioeconômicas e a transmissão de dengue. Rev Saúde Pública 2007; 41:923-30.

11. Ribeiro AF, Marques GRAM, Voltolini JC, Condino MLF. Associação entre incidência de dengue e variáveis climáticas. Rev Saúde Pública 2006; 40:671-6.

12. Cunha V, Maspero RC, Miagostovich MP. Dengue infection in Paracambi, state of Rio de Janeiro, 1990-1995. Rev Soc Bras Med Trop 1997; 30:37983.

13. Corrêa PRL, França E, Bogutchi TF. Infestação pelo Aedes aegypti e ocorrência da dengue em Belo Horizonte, Minas Gerais. Rev Saúde Pública 2005; 39:33-40.

14. Coelho GE, Buratinni MN, Teixeira MG, Coutinho FAB, Massad E. Dynamics of the 2006/2007 dengue outbreak in Brazil. Mem Inst Oswaldo Cruz 2008; 103:535-9.

15. Flauzino RF, Souza-Santos R, Oliveira RM. Dengue, geoprocessamento e indicadores socioeconômicos e ambientais: um estudo de revisão. Rev Panam Salud Pública 2009; 25:456-61.

16. Organização Pan-Americana da Saúde. Número de casos notificados de dengue e febre hemorrágica da dengue (FHD), região das Américas, 2006. http:// www.paho.org/English/AD/DPC/CD/denguecases-2006.html (accessed on Jul/2008).
17. Secretaria Municipal de Saúde e Defesa Civil. Casos de incidência de Dengue por bairro e mês no Município do Rio de Janeiro - 2006. http:/ /www. saude.rio.rj.gov.br/saude (accessed on Jul/2008).

18. Alem A. Breve relato sobre a formação das Divisões Administrativas na cidade do Rio de Janeiro: período de 1961 a 2007. http:/ /www.armazemdedados. rio.rj.gov.br/arquivos (accessed on Jul/2008).

19. Teixeira TRA. Análise espacial e temporal da dengue no contexto sócio-amiental do município do Rio de Janeiro: 1996-2006 [Masters Thesis]. Rio de Janeiro: Escola Nacional de Saúde Pública Sergio Arouca, Fundação Oswaldo Cruz; 2009.

20. Camargo ECG, Druck S, Câmara G. Análise espacial de superfícies. In: Druck S, Carvalho MS, Câmara G, Monteiro AMV, organizadores. Análise espacial de dados geográficos. Planaltina: Empresa Brasileira de Pesquisa Agropecuária; 2004. p. 79-122.

21. Cavallieri F, Lopes GP. Índice de desenvolvimento social - comparando as realidades microurbanas da cidade do Rio de Janeiro. http://www.armazem dedados.rio.rj.gov.br/arquivos/2247_índice\%20 de\%20desenvolvimento\%20social\%20_\%20ids. PDF (accessed on Dec/2008).

22. Hammond R, McCullagh PS. Quantitative Techniques in geography: an introduction. Oxford: Clarendon Press; 1978.

23. Câmara G, Carvalho MS, Cruz OG, Correia V. Análise espacial de áreas. In: Druck S, Carvalho MS, Câmara G, Monteiro AMV, organizadores. Análise espacial de dados geográficos. Planaltina: Empresa Brasileira de Pesquisa Agropecuária; 2004. p. 155-205.

24. Tassinari WS, Pellegrini DCP, Sabroza PC, Carvalho MS. Distribuição espacial da leptospirose no Município do Rio de Janeiro, Brasil, ao longo dos anos de 1996-1999. Cad Saúde Pública 2004; 20:1721-9.

25. Carvalho MS, Cruz OG, Nobre FF. Perfil do risco: método multivariado de classificação socioeconômica de microáreas urbanas - os setores censitários da região metropolitana do Rio de Janeiro. Cad Saúde Pública 1997; 13:635-45.

26. Guha-Sapir D, Schimmer B. Dengue fever: new paradigms for a changing epidemiology. Emerg Themes Epidemiol 2005; 2:1.

27. Degallier N, Teixeira JMS, Soares SS, Pereira RD, Pinto SCF, Chaib AJM, et al. Aedes albopictus may not be vector of dengue virus in human epidemics in Brazil. Rev Saúde Pública 2003; 37:386-7.

28. Fundação Nacional de Saúde, Ministério da Saúde. Programa Nacional de Controle da Dengue. Brasília: Ministério da Saúde; 2002.

29. Luz PM, Codeço CT, Massad E, Struchiner CJ. Uncertainties regarding dengue modeling in Rio de Janeiro, Brazil. Mem Inst Oswaldo Cruz 2003; 98:871-8.

Submitted on 10/Dec/2009

Final version resubmitted on 17/Jun/2010 Approved on 29/Jun/2010 